\title{
The Problem of Densification of Large-Panel Housing Estates upon the Example of Cracow
}

\author{
Eliza Szczerek
}

check for updates

Citation: Szczerek, E. The Problem of Densification of Large-Panel Housing Estates upon the Example of Cracow. Land 2021, 10, 1359. https://doi.org/ 10.3390/land10121359

Academic Editors: Jan K. Kazak,

Katarzyna Hodor and

Magdalena Wilkosz-Mamcarczyk

Received: 2 November 2021

Accepted: 6 December 2021

Published: 9 December 2021

Publisher's Note: MDPI stays neutral with regard to jurisdictional claims in published maps and institutional affiliations.

Copyright: (C) 2021 by the author. Licensee MDPI, Basel, Switzerland. This article is an open access article distributed under the terms and conditions of the Creative Commons Attribution (CC BY) license (https:/ / creativecommons.org/licenses/by/ $4.0 /)$.
Faculty of Architecture, Cracow University of Technology, 31-155 Cracow, Poland; eszczerek@pk.edu.pl

\begin{abstract}
The paper focuses on the phenomenon of intense, uncontrolled densification of large-panel housing estates in Poland. Despite the fact that such housing estates as a legacy of the Modernist concept of segregation of functions are often burdened with problems, they still have considerable potential, which results predominantly from their urban advantages, such as functional and spatial logic, large amounts of open public space, and abundance of greenery. Unfortunately, this potential is being destroyed by introducing new buildings, ignoring the existing urban layout of the housing estate along with its original compositional assumptions. This type of densification results fromwithout limitations - the pressure exerted by developers in the free-market economy, and it often leads to problems such as the devastation of urban layouts of these housing estates, breaking the continuity of public spaces, appropriation of green areas, strengthening of monofunctionality, etc. This problem is becoming noticeable in the scientific debate, although it is still difficult to obtain reliable data illustrating the densifications of such housing estates. The goal of this paper is to present the scales and character of such densifications of the large-panel housing estates, which pose a threat of devastation of their urban layouts often considered as urban heritage. The paper proposes a method of a quantitative analysis of the housing estates with reference to the increase in the built-up area and a qualitative analysis of the character of development with reference to its distribution. This method comprises a sequence of subsequent steps with relevant criteria. In the results, it demonstrates the scale of the problem, which in many cases is already big and still growing. The resultant threat of devastation of the urban layout and its consequences are presented upon selected examples of housing estates in Cracow, Poland. This paper is a voice in a discussion devoted to the current status, but most of all to the future of large-panel housing estates, particularly in terms of their protection as valuable achievements of urban planning of the second half of the 20th century, and to stopping unfavorable tendencies of urban destruction.
\end{abstract}

Keywords: urban densification; prefabricated housing estates; spatial devastation; protection of urban layout; Cracow

\section{Introduction}

The modernist urban thought breaking with the hitherto understanding of urbanity held in the spirit of the doctrine contained in the Athens Charter [1] changed the course and direction of the development of many cities. Years of looking for a new formula of housing contributed-among others-to the development of housing estate structures, which-in contrast to the conventional urban tissue based on the pattern of a street and a square-promoted detached apartments blocks, which were to secure optimal ventilation, insolation, and access to green areas.

The second part of the 20th century saw more and more new housing estates built in Europe. It was a period of economic and demographic development, which accompanied the reconstruction of towns and cities after the war. A crucial role in this respect was played by the industrialization of construction technologies. Advancement in prefabrication processes accelerated the process of building housing estates considerably. Their most prominent development took place in countries of Eastern Europe, where the centrally 
controlled housing market, an element of the planning strategy of the communist regime, fostered the emergence of large-panel housing estates. Cheap and effective solutions in the housing sector were promoted and implemented with great elan and on a large scale.

In Poland, housing estate structures, most commonly executed in the 1970s, have become inherent elements of landscapes of numerous towns and cities. Their scale is quite significant-in 2016, as much as $40 \%$ of urban households were situated in apartment buildings from 1956-1989, mainly in housing estates built in industrialized technologies [2]. It is estimated that in 2020, 30\% of residents of Poland (ca. 12 million people) lived in large-panel blocks [3].

Prefabricated housing estates, which constitute a legacy of the modernist segregation of functions, are a difficult heritage in terms of their architecture and urban planning. They are often burdened with a number of spatial problems, such as monofunctionality, monotony of development, repetitiveness of forms, low-quality architecture of apartments buildings, amorphous and undefined spaces, or spatial degradation and isolation [4-8], as well as social ones [9-11] including stigmatization, negative image [12,13], and safety issues [14]. On top of that, there are technical problems associated with the low quality of materials used [15] and poor energy performance [16], although the latter has been dealt with to a great extent by broadly implemented insulation and window replacement projects.

More and more often, large-panel housing estates in Poland are recognized as crisis areas [17]. Nevertheless, the threat of their physical and social degradation is not as big as in similar housing estates in Western Europe, which is predominantly connected with a gap in the housing market as well as a demand for relatively inexpensive apartments [18]. Furthermore, Poland still demonstrates a considerable housing deficit of ca. 640,000 apartments [19]. In relation to the housing estates in Western Europe, it seems that the estates in post-socialist cities will undergo changes according to their own scenarios [20].

Yet, despite many negative phenomena, large-panel housing estates still have considerable potential, resulting predominantly from their urban values and public open spaces associated with them [21]. Frequently, they are characterized by a functional and spatial logic as well as abundance of green areas, which are strongly related to the residential development [22-24]. Time and again, the overall urban layout of a housing estate corresponds to local conditions, making use of such natural advantages as the lay of the land or the vicinity of valuable landscapes [8]. Thus, many of them constitute valuable testimonies to urban planning achievements of Late Modernism, which require adequate protection [3,25].

Against the background of many contemporary housing estates, large-panel housing estates create a housing environment of a better quality and constitute a favorable living environment [26,27]. In many contemporary housing estates, we have to deal with spatial and social problems [28-30]. Small distances between buildings-although still consistent with legal regulations, 'peering into windows', or fencing, the latter being a hallmark of social exclusion, are their standard elements. There is not enough park and public greenery, sports and recreation grounds, sufficient services, education, trade, etc. Consequently, more and more frequently, the contemporary multi-family architecture is referred to as 'housing pathology' [31,32].

In the context of large-panel housing estates, they may pose a particular risk due to two aspects. Firstly, individual buildings or clusters thereof sprawl within the perimeter of housing estates, appropriating valuable open space and destroying their urban composition. Secondly, in many newly erected contemporary developments with multi-family buildings located in the direct vicinity of large-panel housing estates, residents use the existing infrastructure of large-panel housing estates, comprising e.g., schools, healthcare facilities, as well as greenery, as there are no legal regulations that would impose the obligation to build such facilities, as it used to be the case before the planning system reform [29]. Thus, besides certain services in ground floors, such housing estates, oriented toward the highest profits possible generated from residential spaces, often constitute single-use formations, taking a lot from large-panel housing estates but not giving much in return. 
The aforementioned excessive and chaotic densification of large-panel housing estates with new development constitutes a common and significant problem, which may lead to the gradual devastation of such housing estates [33]. It happens that new buildings are placed in the areas, which originally were designed as recreational and leisure zones for residents [34]. Since the new buildings most of all are residential ones, monofunctionality is strengthened even more. New buildings are often fenced to be separated from the remaining parts of housing estates, which additionally disturbs the continuity of public spaces of a housing estate and is unfavorable for establishing appropriate relations in the social dimension. This overlaps with the problem of an increased demand for parking spaces, which also take over the space of housing estates considerably [35-39].

The first tendencies of densification of housing estates in Poland started to emerge as early as in the 1980s. They were caused by-among other factors-policies of housing cooperatives, which recognized selling parts of their territories as more economical than maintaining them in an undeveloped state [40]. Intensification in introducing new buildings can be observed since the 1990s, which was supported by the political transformation and new free market mechanisms it entailed. This new situation coincided with rather inefficient planning mechanisms regulating the spatial development of housing estates. However, to a certain extent, they did ensure the protection of unoccupied areas allocated to the greenery of housing estates under the general masterplan from 1994 covering the entire territory of Poland. The situation changed considerably when this plan was repealed in 2003 and no new one was resolved to replace it. This results in allocating these grounds to buildings, in compliance with the law [41]. Intensified and aggressive pressure exerted by developers has far-reaching spatial consequences, which are expressed predominantly in the aforementioned densification of housing estates. It is particularly unfavorable to them, since their urban layout, composition principles, and green areas are decisive for their character and identity as well as for the way they function.

The process of forming as well as functioning of large-panel housing estates in the communist socio-economic system is generally well known and present in the scientific literature. However, the situation of their spatial change after the political transformation are still not sufficiently recognized and described. The problem of densification of largepanel housing estates is becoming noticeable in the scientific debate; however, there are still not enough sources of data referring to the problem, especially to its scale. These processes of densification intensify gradually, and they affect different housing estates to different extents. Even though noticed by urban planners as well as residents, they have yet to be analyzed and provided with comprehensive databases, which would allow developing a methodological foundation for the assessment of the existing or potential threats, as well as formal and legal solutions that could be undertaken to prevent them.

Therefore, the goal of this paper is to present scales and character of such densifications of large-panel housing estates, which pose a threat of devastation of their urban layouts often considered as urban heritage $[2,3,25]$. Conclusions formulated in this paper may constitute a source of information on tendencies of spatial changes happening in such housing estates as well as provide inspiration to undertake systematic measures toward the rationalization of these processes.

This paper fills a gap in the state of the art concerning the problem of the threat of devastation of the urban layouts of large-panel housing estates in Poland, which are also understood as the structures of urban heritage, caused by chaotic densification, after the introduction of a free-market economy as a result of the transformation of the political system.

The article is divided into five parts. Following the Introduction, Section 2 describes the study area-Cracow large-panel housing estates-and introduces methods comprising a sequence of subsequent steps with relevant criteria, as well as provides datasets sources. Section 3 presents the result of the quantitative analysis related to the scale of densifications as well as a qualitative analysis related to their spatial character. Additionally, an in-depth analysis of selected examples is presented to support the research findings. In Section 4, 
the author discusses the results in a broader context, referring to selected aspects. Section 5 concludes with a summary of the main results of this research and highlights future research directions.

\section{Materials and Methods}

\subsection{Study Area-Cracow Large-Panel Housing Estates}

The study area comprised large-panel housing estates in Cracow (Figure 1)-the main city of the Province of Małopolskie. As the second largest city of Poland, besides the local specificity characteristic for each settlement market with a specific individuality, it demonstrates many tendencies and mechanisms characteristic of big cities. Thus, it illustrates the problems that concern large-panel housing estates in other Polish cities. In addition, a significant number of prefabricated housing estates in Cracow allows for a broader study of the problem.

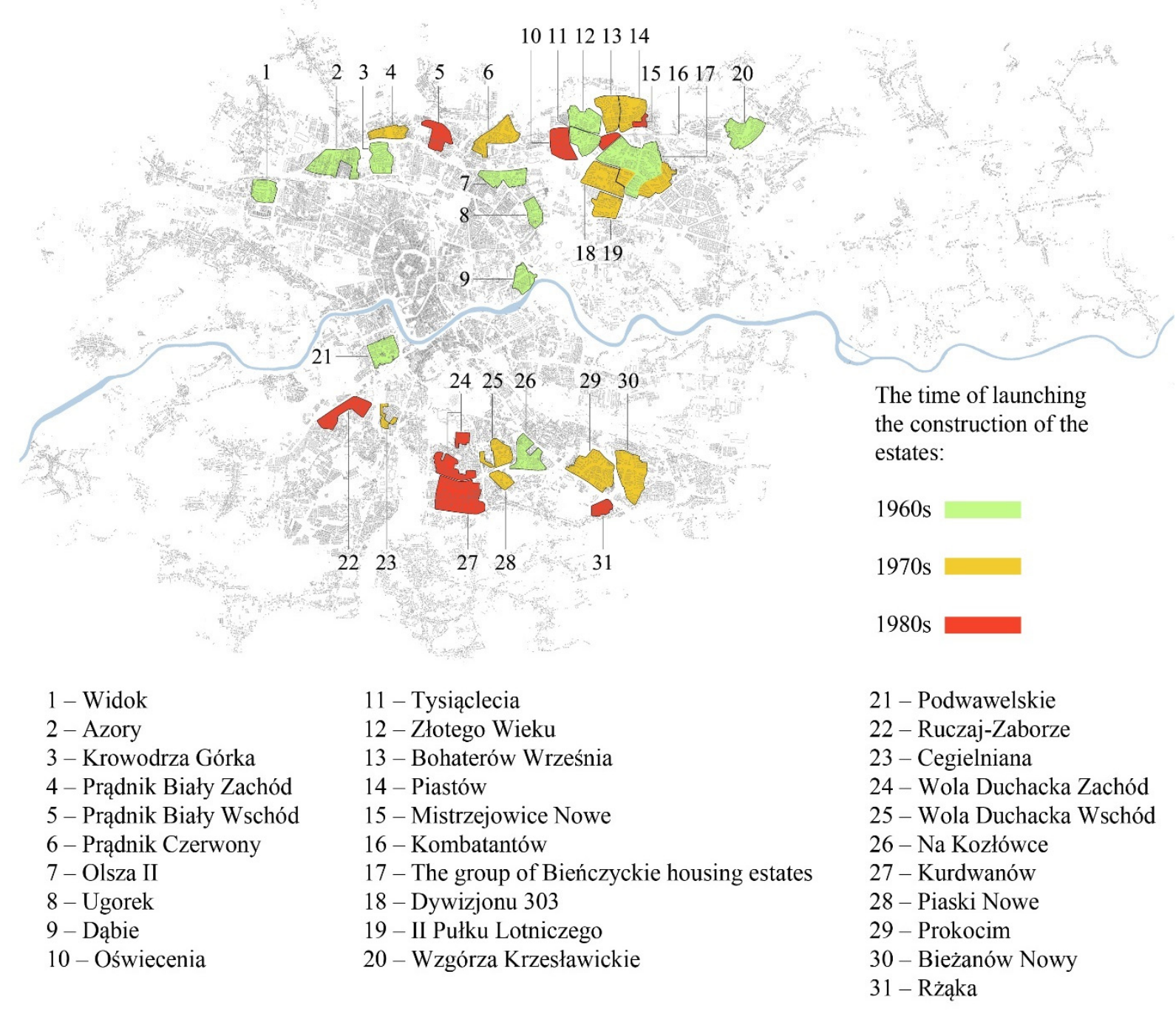

Figure 1. Arrangement of large-panel housing estates in the structure of Cracow.

The beginnings of large-panel housing estates in Cracow are associated with the need to provide a large number of apartments, most of all in connection with its constantly growing population after the war. Cracow avoided the need to rebuild its urban structure, including housing resources, as practically, it had not suffered any considerable damage during the war. Housing estates, erected over the span of three decades, were located on the northern and southern side of the city. 
The early 1960s saw the emergence of-among others-housing estates in the northern part of the city, such as Azory and Olsza II, as well as housing estates associated with the extension of the metallurgical plant built in the 1950s, i.e., the Wzgórza Krzesławickie housing estate and shortly after that the first from the group of Bieńczyce housing estates. The late 1960s and early 1970s also marked the beginnings of the construction of such housing estates as Krowodrza, Widok, Dabie, and Pradnik Czerwony. The extension of the development of Nowa Huta was also continued, with a group of four Mistrzejowice housing estates erected there: Tysiąclecia, Złotego Wieku, Bohaterów Września, and Piastów [42]. At the same time, the Podwawelskie and Na Kozłówce housing estates were emerging on the southern bank of the Vistula.

The emerging new developments affected the gradual change of the spatial layout of Cracow from a bipolar to a band-shaped one. The 1970s is a period when distances between one's workplace and residence increased considerably, and the existing tramway no longer sufficed, as it was overloaded. It was a time when a network of bus connections got extended. The year 1973 saw another broadening of the city's administrative limits aimed to mitigate the deficit of construction lands [43]. The subsequent development of the city was based on a plan adopted in 1977, which had a significant impact upon the process of forming housing estates. The plan assumed two parallel bands of development coexisting together, with the historic city center as their keystone [44,45]. In addition to the housing estates whose construction had already begun in the southern band, i.e., Prokocim Nowy and Piaski Nowe, toward the end of the 1970s, the construction of the next housing estates was commenced: Bieżanów Nowy and Wola Duchacka Wschód. In the northern bank, after moving the airport from Czyżyny to Balice, the development of these areas started in 1978, with the Dywizjonu 303 housing estate built to the north from the runway and the II Pułku Lotniczego housing estate to the south from it.

In the 1980s, the construction of this housing estate was continued, but also new ones started to emerge. The Kombatantów housing estate was built in the norther band, which was followed later by the Oświecenia housing estate. Wola Duchacka Zachód, Kurdwanów, and Ruczaj-Zaborze developments were erected in the southern band.

Sporadically, the construction of housing estates continued to the early 1990s, with the Rżaka housing estate as an example. In the ornamentation of its architectural details, it makes a reference to the aesthetics of Post Modernism, which were for the first time applied in Cracow in industrialized residential developments [29]. In the early 1990s, the construction of the Mistrzejowice Nowe housing estate was continued as well.

Housing estates built with the application of industrialized technologies are a significant element in the urban structure of Cracow in terms of territory. Housing developments from the 1960s and early 1970s constitute ca. 25\% of all apartments located in the city. The highest number of apartments, ca. 35\%, are located in housing estates built in the 1970s and early 1980s [44].

The greatest accumulation of housing estates is in the eastern part of the city, particularly in the northern band, where the extension of the metallurgical plant in Nowa Huta mentioned above was an important stimulus for their coming into being. Even though these housing estates were built in different times and most often are independent from each other in administrative terms, they form a vast complex of housing estates due to their often direct proximity. It has its effect on the identity of this part of the city, which to a great extent is identified with this type of architecture.

Housing estates located in the southern part of the city due to the considerable area they occupy strongly define the character of this part of Cracow as well. However, in contrast to housing estates in Nowa Huta, they do not often border on one another. A feature that can be recognized as characteristic is the fact that they appear as islands among areas of one-family houses, which divide housing estates into separate clusters. Such a situation can be observed in Wola Duchacka, which is a housing estate that is formally divided into an eastern and western part, with the latter additionally consisting of two 'islands' of large-panel buildings. Furthermore, similarly to the Cegielniana and 
Na Kozłówce housing estates, the territory occupied by large-panel buildings assumes a shape resembling the letter ' $U$ ', surrounding one-family houses. In the northern part, a similar situation can be seen in the Azory housing estates, which are visibly interspersed with one-family houses.

In Cracow, many housing estates from the second half of the 20th century are recognized as areas requiring many issues to be resolved [44] and they have been covered by the 'Program of Multi-family Housing Development Rehabilitation in the Area of Cracow Municipal Commune' [46]. As in many other Polish towns and cities, currently, one of the biggest problems of Cracow is the chaotic densification of such housing estates with new buildings. The way the lands are administered is not beneficial for the spatial situation of housing estates in Cracow. Most lands, even though they are the property of the Municipality of Cracow, are lent for use to numerous entities, and consequently, there is no direct control over them, which in turn makes it harder to make any comprehensive decisions. Furthermore, due to more and more frequent cases of buying them up by different entities, this situation may worsen still [41], since-as it has been mentioned before- their densification is often chaotic, with no respect for the entire context and no well-considered, holistic approach. One of the consequences of densification of housing estates is their fragmentation, which is caused by fencing off areas and by the loss of spatial cohesion due to taking green areas over by cars.

\subsection{Methods}

The base for pursuing the research goal referring to the scale and the character of urban densifications of the housing estates from the second half of the 20th century is provided by the author's literature studies $[8,20,33,34,38,39,47]$ and scientific experience in this subject matter. This paper presents a more detailed insight into threats to large-panel housing estates, basing on numerical and qualitative data, extending the knowledge in this field. It fills the gap in the existing studies focusing on this problem, particularly in the context of devastation of valuable urban layouts of such housing estates, which are recognized as heritage.

Currently, it is difficult to obtain data illustrating the problem of densification of such housing estates. Different methods are characteristic for the discipline of science: Architecture and Urban Planning have been applied in an attempt to characterize this problem upon the example of Cracow [48]. They are presented in the following steps:

- Step 1. Indication of the analyzed housing estates within the city limits (Figure 1).

Qualitative criteria: Construction technology, time and place of construction, genesis, urban compositional layout.

Comment: The analysis covers housing estates built in industrialized technologies (initially in the large-block technology and then in large-panel technologies, which were used on a large scale across European countries, especially in Eastern Europe). Therefore, for the sake of clarity and simplification of deliberations in this paper, they are predominantly referred to as large-panel housing estates. Sometimes, they are also referred to as prefabricated housing estates or estates built in industrialized technologies. Ultimately, all these phrases refer to the same kind of housing estates and are used interchangeably.

The article refers to housing estates that were built on a large scale in Cracow in the second half of the 20th century. The time adopted is connected with the political systemthe time of the communist rule, which had a significant impact on the process of designing such housing estates.

Such housing estates constitute a legacy of the modernist segregation of functions and urban composition, as they were built in the spirit of modernist ideas promoted by the Athens Charter [1].

- $\quad$ Step 2. Defining the areas of the analyzed housing estates (Figure 2).

Quantitative criterion: Housing estate's boundary. 
Comment: Areas of selected housing estates were defined following Lynch's 'district' category [49], which is understood as a homogenous area with a uniform character in which one has a feeling of being inside or outside of this area.

- Step 3. Characterization of densifications of the analyzed housing estates.

Quantitative criterion: Increase in the built-up area [\%] (Table 1, Figure 3).

Qualitative criterion: Characteristics of the way new buildings are introduced:

- Densification within the perimeter of the housing estate (Figure 4);

- Densifications on the outskirts of the housing estate-shifting its edge and increasing the original area of the housing estate (Figure 5).

Comment: The increase in the built-up area in the housing estates was defined quantitatively, comparing figures from the mid-1990s and 2021. This time cut-off point is connected with a radical transformation of the political, economic, and social system in Poland, which had a significant impact on such housing estates. The mid-1990s is a transitional period between the already collapsed centralized national economy during the communist time and a newly emerging free market system of a democratic reality. The centrally controlled housing market within the communist regime promoted the implementation of such big spatial and functional urban projects, including large-panel housing estates. With the political transformation and the free market economy, a completely new mechanism in the housing market and urban planning appeared. Even though 1989 was a breakthrough year for the social and political system in Poland, the processes associated with designing such housing estates were sometimes continued in the early 1990s. That is why 1995 was selected as a turning point in the analysis performed, where figures from the mid-1990s and 2021 were compared.

The percentage of the increase in the built-up area was determined by comparing data from a vector map obtained from the City Hall Cracow and other maps available online within the scheme of the Municipal Spatial Information System for Cracow [50] with data from satellite images from 1995.

An analysis was performed covering the densification of central areas of housing estates as well as their peripheral zones, causing disturbances of spatial edges.

- Step 4. Reference to the urban heritage structures and local spatial development plans in the context of the housing estates (Table 2).

Quantitative criterion (a): Recognition of the estates as urban heritage structures.

Quantitative criterion (b): Presence of local spatial development plans:

- $\quad$ For the entire territory of the housing estate;

- $\quad$ For a part of the territory of the housing estate or its edge (adjacent areas).

Comment: Housing estates as urban heritage structures were indicated on the basis of the results of a research project [2]. An analysis of coverage of large-panel housing estates with local spatial development plans was performed on the basis of information available in the Public Information Bulletin of the City of Cracow [51].

- Step 5. Indication of monofunctional clusters of apartment blocks in the vicinity of large-panel housing estates. (Figures 6 and 7, Table 3).

Quantitative criterion: Presence of such clusters in areas adjacent to the large-panel housing estates.

Comment: Such complexes of monofunctional residential areas may have a negative impact on the functioning of the housing estates (described in more detail in the Introduction).

- Step 6. An in-depth description of selected examples of housing estates with a valuable urban composition (Figures 8-11).

Qualitative criterion: High spatial devastation of the urban layout of the housing estate, which is caused by intensive densification with new buildings.

Comment: This is to illustrate more vividly the threat of devastation of their urban layouts. 
Results of the analyses are presented in a form of a systematic overview of changes within housing estate structures and in areas adjacent to them caused by their densification as well as diagrams illustrating this problem quantitatively.

\section{Results}

While analyzing spatial metamorphoses within the perimeter of large-panel housing estates in Cracow, it was noticed that their densifications assume different scales and characters and most importantly affect nearly all the housing estates. It is particularly striking in the case of urban layouts of such housing estates with high compositional values, which have been recognized as structures of urban heritage. New buildings were not observed only in one housing estate (Figure 2, Table 1).

Table 1. Densification values for large-panel housing estates in Cracow (\%).

\begin{tabular}{|c|c|c|c|}
\hline & Housing Estates in the Northern Part of the City & Buildings Erected before 1995 & $\begin{array}{l}\text { New Buildings Erected } \\
\text { between } 1995 \text { and } 2021\end{array}$ \\
\hline 1 & Widok & $90.1 \%$ & $9.9 \%$ \\
\hline 2 & Azory & $89.1 \%$ & $10.9 \%$ \\
\hline 3 & Krowodrza Górka & $77.4 \%$ & $22.6 \%$ \\
\hline 4 & Prądnik Biały Zachód & $89.8 \%$ & $10.2 \%$ \\
\hline 5 & Prądnik Biały Wschód & $93.8 \%$ & $6.2 \%$ \\
\hline 6 & Prądnik Czerwony & $86.4 \%$ & $13.6 \%$ \\
\hline 7 & Olsza II & $93.8 \%$ & $6.2 \%$ \\
\hline 8 & Ugorek & $97.3 \%$ & $2.7 \%$ \\
\hline 9 & Dąbie & $80.2 \%$ & $19.8 \%$ \\
\hline 10 & Oświecenia & $69.4 \%$ & $30.6 \%$ \\
\hline 11 & Tysiąclecia & $96.6 \%$ & $3.4 \%$ \\
\hline 12 & Złotego Wieku & $91.9 \%$ & $8.1 \%$ \\
\hline 13 & Bohaterów Września & $71.8 \%$ & $28.2 \%$ \\
\hline 14 & Piastów & $89.1 \%$ & $10.9 \%$ \\
\hline 15 & Mistrzejowice Nowe & $94.5 \%$ & $5.5 \%$ \\
\hline 16 & Kombatantów & $98.3 \%$ & $1.7 \%$ \\
\hline 17 & The Group Of Bieńczyckie Housing Estates & $90.5 \%$ & $9.5 \%$ \\
\hline 18 & Dywizjonu 303 & $65.8 \%$ & $34.2 \%$ \\
\hline 19 & II Pułku Lotniczego & $80.8 \%$ & $19.2 \%$ \\
\hline 20 & Wzgórza Krzesławickie & $94.1 \%$ & $5.9 \%$ \\
\hline \multicolumn{4}{|c|}{ Housing estates in the southern part of the city } \\
\hline 21 & Podwawelskie & $79.0 \%$ & $21.0 \%$ \\
\hline 22 & Ruczaj-Zaborze & $91.9 \%$ & $8.1 \%$ \\
\hline 23 & Cegielniana & $100.0 \%$ & $0.0 \%$ \\
\hline 24 & Wola Duchacka Zachód & $90.3 \%$ & $9.7 \%$ \\
\hline 25 & Wola Duchacka Wschód & $79.2 \%$ & $20.8 \%$ \\
\hline 26 & Na Kozłówce & $84.2 \%$ & $15.8 \%$ \\
\hline 27 & Kurdwanów & $70.0 \%$ & $30.0 \%$ \\
\hline 28 & Piaski Nowe & $97.0 \%$ & $3.0 \%$ \\
\hline 29 & Prokocim & $90.0 \%$ & $10.0 \%$ \\
\hline 30 & Bieżanów Nowy & $74.8 \%$ & $25.2 \%$ \\
\hline 31 & Rżąka & $85.6 \%$ & $14.4 \%$ \\
\hline
\end{tabular}

\subsection{Quantitative Characteristics of Densifications}

The quantitative analysis of the increase in built-up areas in the housing estates covered their territories, taking into account their possible extensions if their edges were shifted due to adding new buildings (situations referred to in Section 3.2 as A and B). Quantitative results are presented below (Table 1, Figure 3). The table contains values illustrating the development of the housing estates with reference to the area increased by newly erected buildings: the first column refers to buildings from before 1995, the second refers to buildings erected after 1995 to date (2021). 


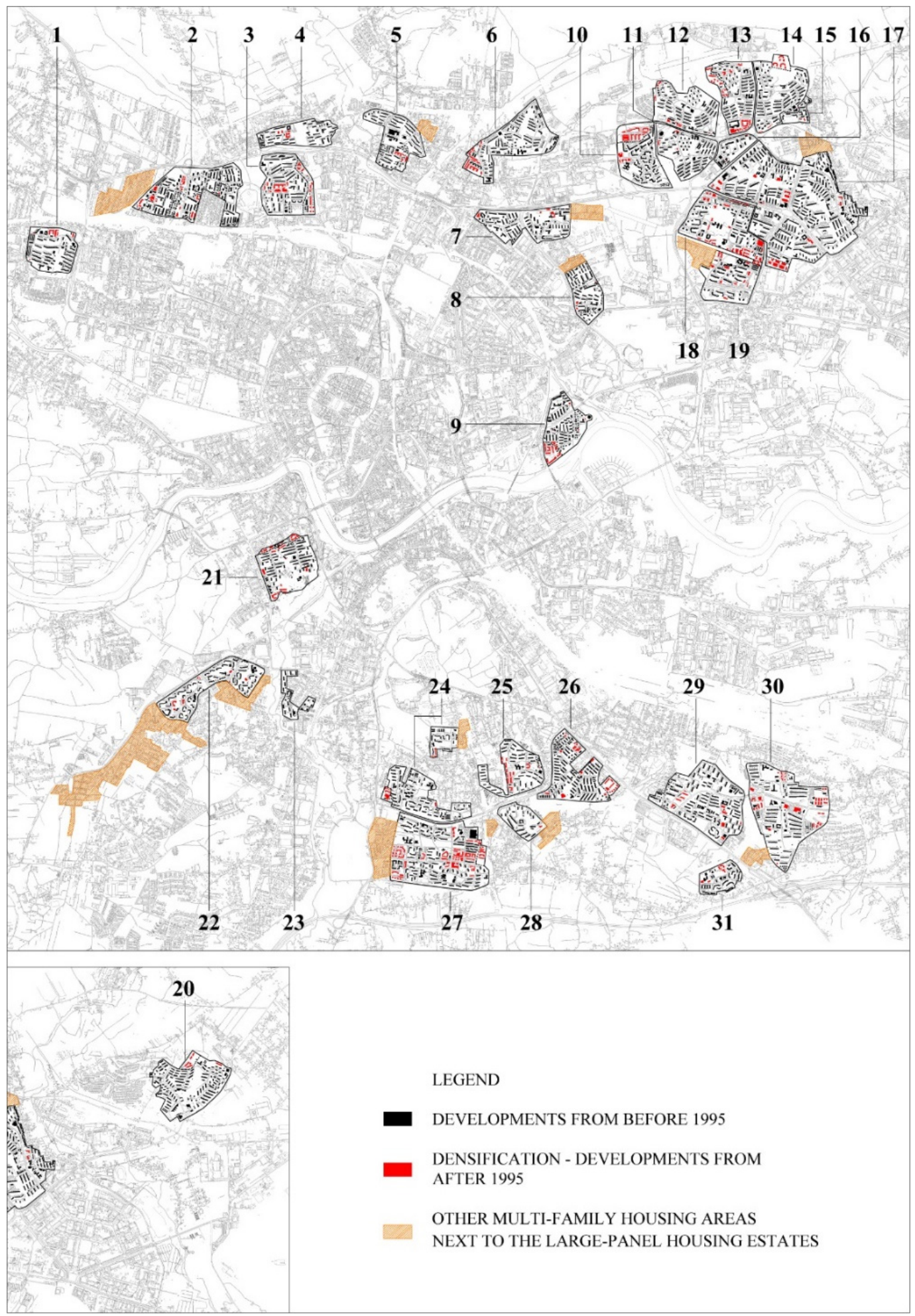

Figure 2. Map of a part of Cracow with areas of the analyzed housing estates marked (black border). 1-Widok, 2-Azory, 3-Krowodrza Górka, 4-Prądnik Biały Zachód, 5-Prądnik Biały Wschód, 6-Prądnik Czerwony, 7-Olsza II, 8-Ugorek, 9-Dąbie, 10-Oświecenia, 11-Tysiąclecia, 12-Złotego Wieku, 13-Bohaterów Września, 14—Piastów, 15-Mistrzejowice Nowe, 16-Kombatantów, 17-The group of Bieńczyckie housing estates, 18-Dywizjonu 303, 19—II Pułku Lotniczego, 20Wzgórza Krzesławickie, 21-Podwawelskie, 22-Ruczaj-Zaborze, 23-Cegielniana, 24—Wola Duchacka Zachód, 25-Wola Duchacka Wschód, 26-Na Kozłówce, 27-Kurdwanów, 28-Piaski Nowe, 29—Prokocim, 30—Bieżanów Nowy, 31-Rżąka. 


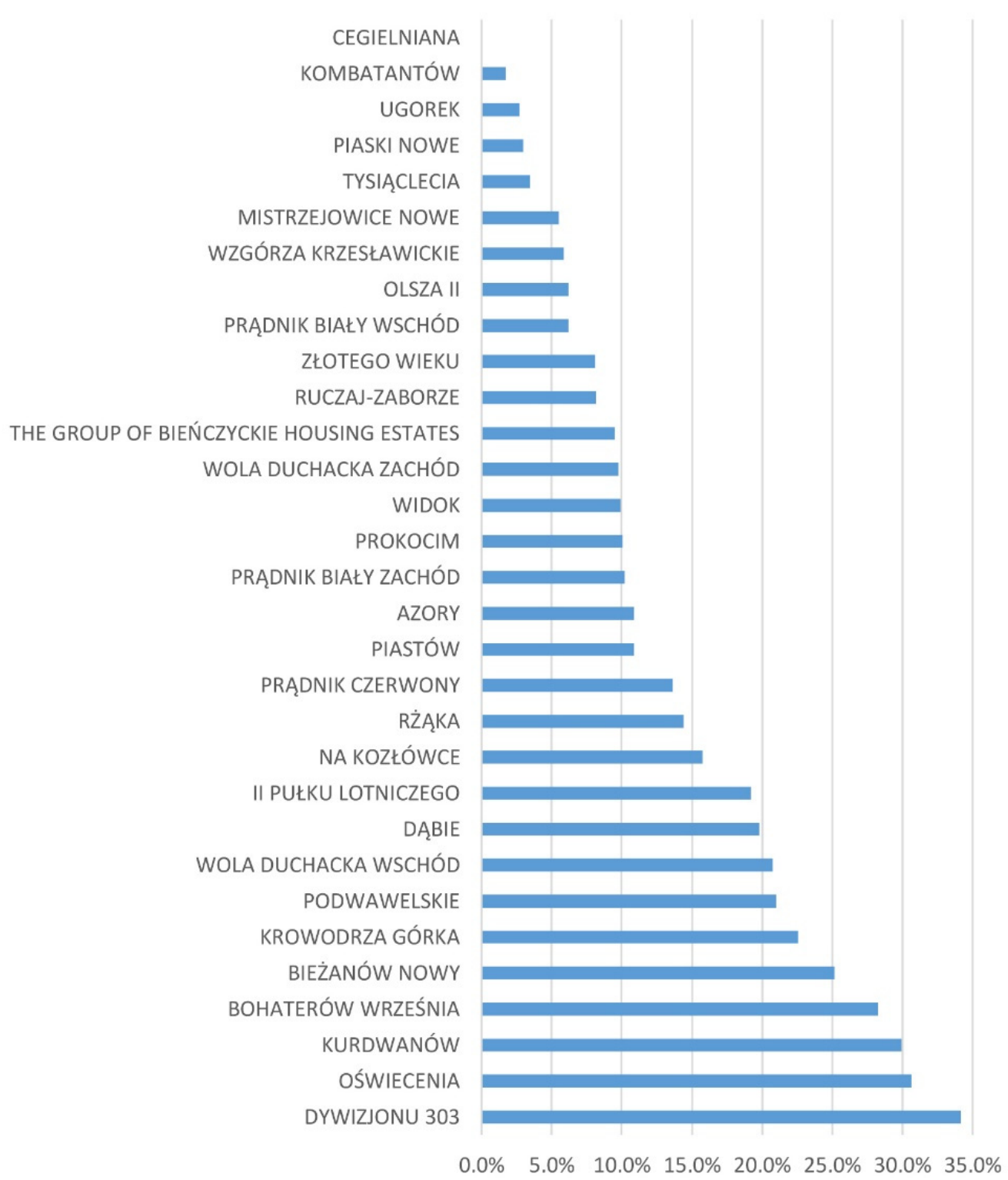

Figure 3. Diagram illustrating a relative development increase in large-panel housing estates in Cracow.

An analysis of the increase in the built-up area demonstrates that densifying housing estates with new buildings is more intensive in the southern part of the city, and on average, it reaches $18.2 \%$. The average increase in built-up areas in the northern housing estates is $13.8 \%$. The total average for all the housing estates is $15.4 \%$.

The biggest number of housing estates-14-increased their built-up area within the range of 1 to $10 \%$. Eight housing estates were in the range $10-20 \%$. In six housing estates, the increase is at the level of over $30 \%$. The housing estates that stand out due to the largest increase in the built-up area, i.e., 30\% or more, are Kurdwanów, Dywizjonu 303, and Oświecenia housing estates.

One of the methods of controlled development of housing estates can be local spatial development plans. Some of the housing estates in Cracow have such plans drawn up, covering their entire perimeter or a part thereof. It was also verified whether similar plans cover adjacent areas, which might be significant particularly for the protection of green areas around the housing estates (Table 2). It was presented in the context of the information which estates are recognized as urban heritage structures [2] (Table 2). 
Table 2. List of housing estates recognized as urban heritage structures with their entire territories or parts thereof covered with local spatial development plans.

\begin{tabular}{|c|c|c|c|c|}
\hline & $\begin{array}{l}\text { Housing Estates in the } \\
\text { Northern Part of the City }\end{array}$ & $\begin{array}{l}\text { Housing Estates } \\
\text { Recognized as Urban } \\
\text { Heritage Structures [2] }\end{array}$ & $\begin{array}{l}\text { Local Spatial Development } \\
\text { Plan for the Entire Territory } \\
\text { of the Housing Estate }\end{array}$ & $\begin{array}{l}\text { Local Spatial Development } \\
\text { Plan for a Part of the } \\
\text { Territory of the Housing } \\
\text { Estate or Its Edge } \\
\text { (Adjacent Areas) }\end{array}$ \\
\hline 1 & Widok & $x$ & $x$ & \\
\hline 2 & Azory & & $x$ & \\
\hline 3 & Krowodrza Górka & $x$ & & $x$ \\
\hline 4 & Prądnik Biały Zachód & & & $x$ \\
\hline 5 & Prądnik Biały Wschód & $X$ & & $X$ \\
\hline 6 & Prądnik Czerwony & & $x$ & \\
\hline 7 & Olsza II & $X$ & $X$ & \\
\hline 8 & Ugorek & $x$ & $x$ & \\
\hline 9 & Dąbie & $x$ & $x$ & \\
\hline 10 & Oświecenia & $x$ & $x$ & \\
\hline 11 & Tysiąclecia & $x$ & $x$ & \\
\hline 12 & Złotego Wieku & $x$ & $x$ & \\
\hline 13 & Bohaterów Września & $x$ & & $x$ \\
\hline 14 & Piastów & $X$ & & $x$ \\
\hline 15 & Mistrzejowice Nowe & & & \\
\hline 16 & Kombatantów & & $x$ & \\
\hline 17 & $\begin{array}{c}\text { The Group Of Bieńczyckie } \\
\text { Housing Estates }\end{array}$ & $x$ & $x$ & \\
\hline 18 & Dywizjonu 303 & $x$ & $X$ & \\
\hline 19 & II Pułku Lotniczego & $x$ & $x$ & \\
\hline \multirow[t]{2}{*}{20} & Wzgórza Krzesławickie & $x$ & & $x$ \\
\hline & $\begin{array}{l}\text { Housing estates in the } \\
\text { southern part of the city }\end{array}$ & & & \\
\hline 21 & Podwawelskie & $X$ & & $x$ \\
\hline 22 & Ruczaj-Zaborze & $x$ & & \\
\hline 23 & Cegielniana & & & \\
\hline 24 & Wola Duchacka Zachód & $x$ & & $x$ \\
\hline 25 & Wola Duchacka Wschód & & & \\
\hline 26 & Na Kozłówce & $x$ & & $x$ \\
\hline 27 & Kurdwanów & $x$ & $x$ & \\
\hline 28 & Piaski Nowe & $x$ & & $X$ \\
\hline 29 & Prokocim & $x$ & & $x$ \\
\hline 30 & Bieżanów Nowy & $x$ & & $x$ \\
\hline 31 & Rżąka & & & $x$ \\
\hline
\end{tabular}

Today, i.e., in 2021, 14 out of the 31 analyzed housing estates or their complexes (11 out of the 23 housing estates recognized as urban heritage structures) are covered with local spatial development plans, whereas seven of them have been in force since 2020. Four housing estates are not covered with overall local spatial development plans at all, and 13 housing developments are only in selected parts or on their edges.

\subsection{Qualitative Approach-Characteristics of Spatial Metamorphoses of the Housing Estates}

The analysis of densifications of large-panel housing estates allows defining certain trends in the way new buildings are introduced. These trends are characterized below.

A. New development is introduced as single buildings or clusters of buildings in unoccupied spaces between apartments buildings. It happens both in central areas of housing estates and in their peripheral zones (Figure 4). 


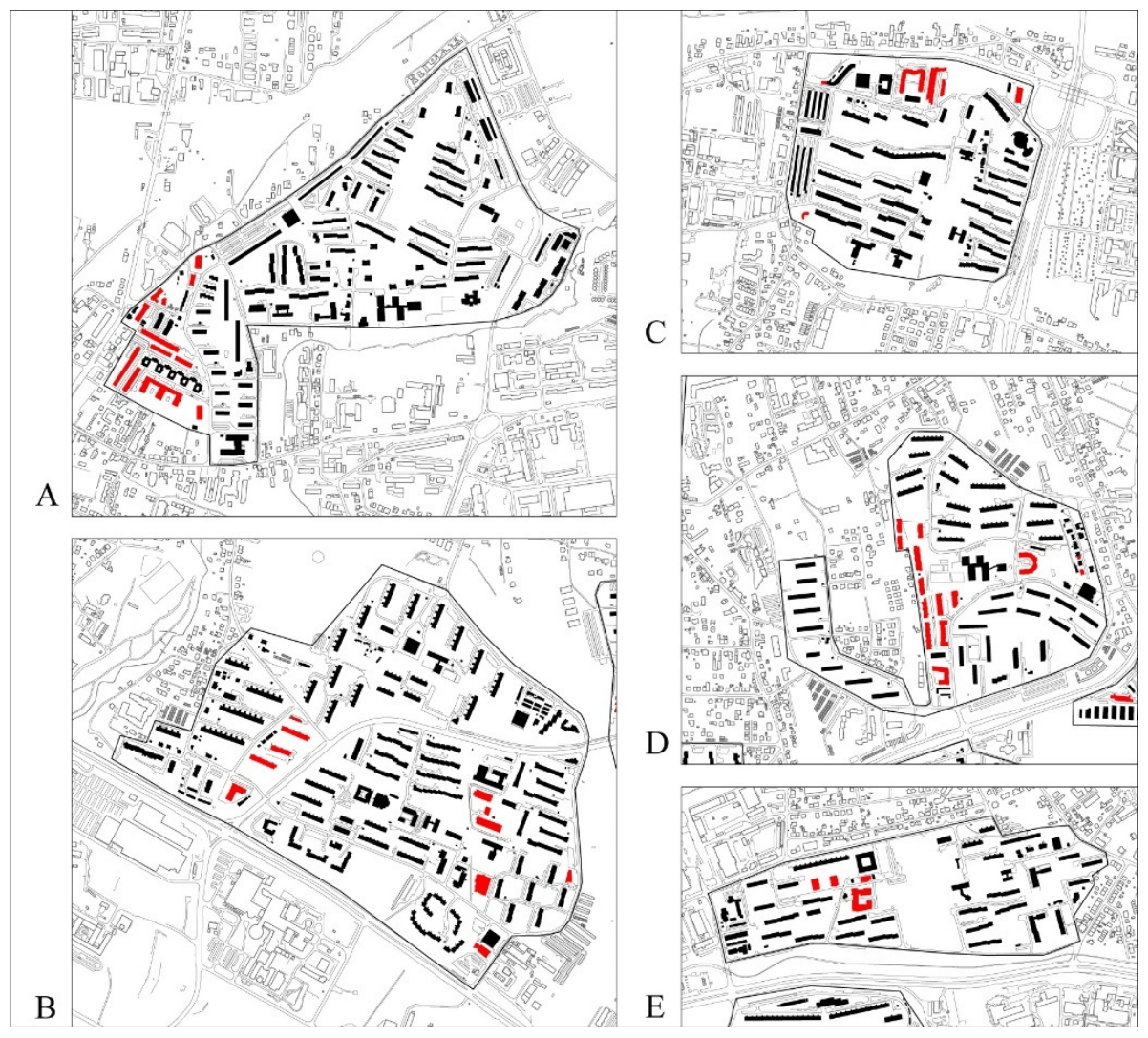

Figure 4. Densification with single or clusters of buildings inside housing estates-selected examples: (A) —Prądnik Czerwony (6), (B)—Prokocim (29), (C)—Widok (1), (D)—Wola Duchacka Wschód (25), (E)—Prądnik Biały Zachód (4). Color legend: black—developments from before 1995; reddensification-developments from after 1995.

B. In situations where new buildings are introduced in the peripheral zones of a housing estate, such buildings tend to push beyond its perimeter, or to push its edge outwards, to be more precise, thus pushing outwards the boundary of the housing estate, informally increasing its territory (Figure 5). It often entails taking over areas that used to constitute green areas: a buffer zone of the housing estate. In densifications of this type, one still can speak of a certain affiliation of new buildings to the structure of the housing estate, at least in terms of belonging to a certain 'district', which is understood in Lynch's categories as an area that is as homogenous as possible, in which one has a feeling of being inside or outside of this area [49]. The affiliation of new buildings to a large-panel housing estate may be also strengthened by a distinct spatial edge located behind it, e.g., a green belt, a river, or a street, particularly a major one.

C. Furthermore, there are situations where a complex of multi-family buildings has been built in the direct vicinity of a housing estate (and frequently, its construction is still in progress), with the dominating residential function and very few accompanying functions. If the scale, character of buildings, and their location toward the existing largepanel housing estate provide them with features that make them stand out, this study does not recognize them as an extension of the housing estate but as a separate structure. Nevertheless, due to the potential influence of such structures on large-panel housing estates mentioned in the introduction, they are included in this paper as the neighborhood of housing estates (Figure 6).

The nature of structural metamorphoses within housing estates and in areas adjacent to them for all the housing states in Cracow according to the tendencies described above is presented in Table 3. 


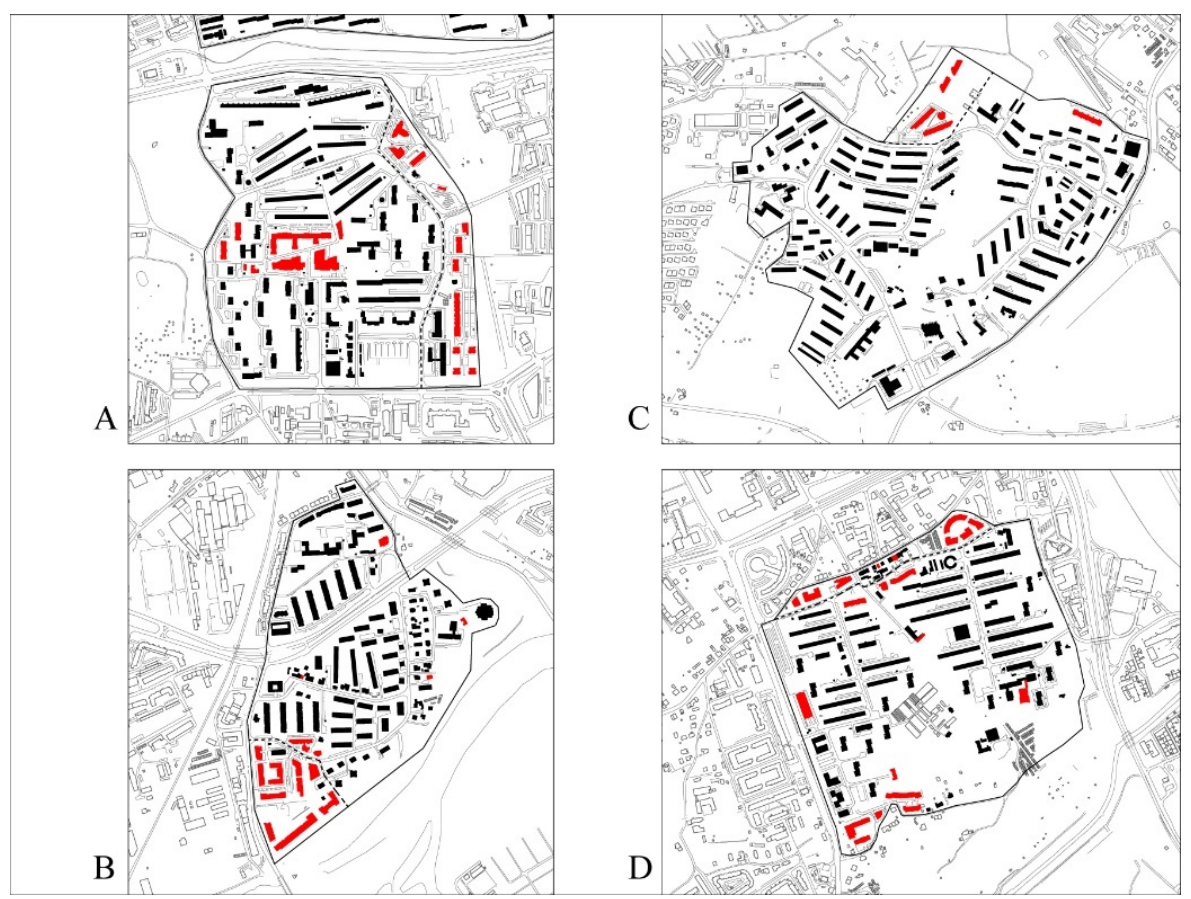

Figure 5. Densification with single buildings or clusters of new buildings on the edges of the housing estates, shifting their boundaries (the extended area is marked with a dotted line) - selected examples of housing estates: (A)—Krowodrza Górka (3), (B)—Dąbie (9), (C)—Wzgórza Krzesławickie (20), (D)—Podwawelskie (21). Color legend: black—developments from before 1995; red-densificationdevelopments from after 1995.

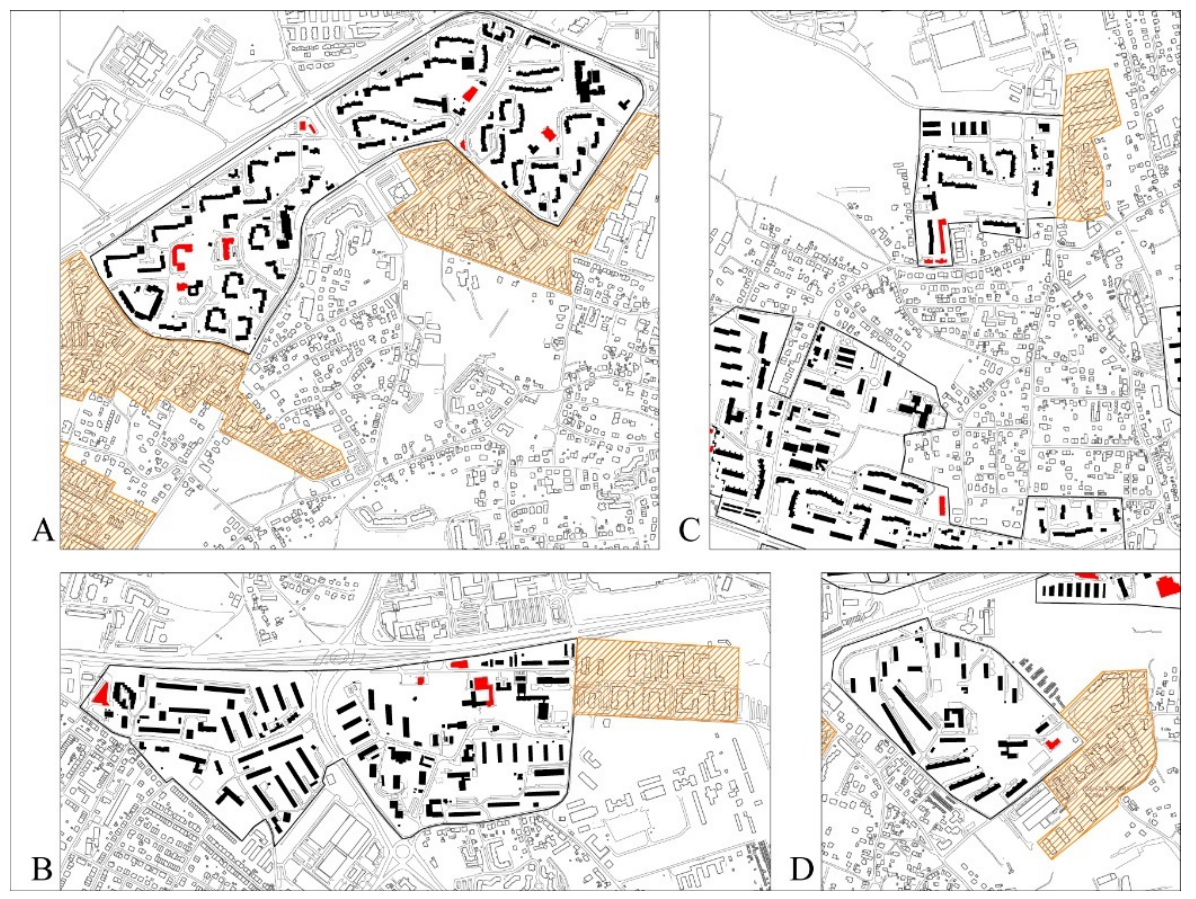

Figure 6. Neighborhood of clusters of multi-family buildings with the dominating residential function —examples in the context of selected housing estates: (A)—Ruczaj (22), (B)—Olsza II (7), (C)—Wola Duchacka Zachód—northern part (4), (D)—Piaski Nowe (28). Color legend: blackdevelopments from before 1995; red—densification-developments from after 1995; orange—other multi-family housing areas next to the large-panel housing estates. 
Table 3. Characteristics of the way new buildings are introduced within the perimeter and in areas adjacent to large-panel housing estates.

B.

A.

Housing Estates in the Northern Part of the City
Densifications within the Perimeter of the Housing Estate
Densifications on the Outskirts of the Housing Estate-Shifting Its Edge and Increasing the Original Area of the Housing Estate
C.

Proximity to an Area of a Multi-Family Complex with the Dominating Residential Function

\begin{tabular}{|c|c|c|c|c|}
\hline & & \multirow{2}{*}{\multicolumn{2}{|c|}{$x$}} & \\
\hline 1 & Widok & & & \\
\hline 2 & Azory & $x$ & & $\mathrm{x}$ \\
\hline 3 & Krowodrza Górka & $x$ & $x$ & \\
\hline 4 & Prądnik Biały Zachód & $x$ & & \\
\hline 5 & Praadnik Biały Wschód & $x$ & & $x$ \\
\hline 6 & Prądnik Czerwony & $\mathrm{x}$ & & \\
\hline 7 & Olsza II & $x$ & & $x$ \\
\hline 8 & Ugorek & $x$ & & $\mathrm{x}$ \\
\hline 9 & Dabie & $x$ & $x$ & \\
\hline 10 & Oświecenia & $x$ & $x$ & \\
\hline 11 & Tysiąclecia & $x$ & & \\
\hline 12 & Złotego Wieku & $\mathrm{x}$ & & \\
\hline 13 & Bohaterów Września & $x$ & $x$ & \\
\hline 14 & Piastów & $x$ & $x$ & \\
\hline 15 & Mistrzejowice Nowe & $x$ & & \\
\hline 16 & Kombatantów & $x$ & & \\
\hline 17 & $\begin{array}{l}\text { The Group Of } \\
\text { Bieńczyckie Housing }\end{array}$ & $x$ & $x$ & $\mathrm{x}$ \\
\hline 18 & $\begin{array}{c}\text { Estates } \\
\text { Dywizjonu } 303\end{array}$ & $\mathrm{x}$ & $\mathrm{X}$ & $\mathrm{x}$ \\
\hline 19 & II Pułku Lotniczego & $x$ & & $x$ \\
\hline \multirow[t]{2}{*}{20} & Wzgórza Krzesławickie & $x$ & $x$ & \\
\hline & $\begin{array}{l}\text { Housing estates in the } \\
\text { southern part of the city }\end{array}$ & & & \\
\hline 21 & Podwawelskie & $\mathrm{x}$ & $\mathrm{X}$ & \\
\hline 22 & Ruczaj-Zaborze & $x$ & & $\mathrm{x}$ \\
\hline 23 & Cegielniana & & & \\
\hline 24 & Wola Duchacka Zachód & $x$ & $x$ & $x$ \\
\hline 25 & Wola Duchacka Wschód & $\mathrm{x}$ & & \\
\hline 26 & Na Kozłówce & $x$ & $x$ & \\
\hline 27 & Kurdwanów & $x$ & $x$ & $x$ \\
\hline 28 & Piaski Nowe & $x$ & & $\mathrm{x}$ \\
\hline 29 & Prokocim & $x$ & & \\
\hline 30 & Bieżanów Nowy & $x$ & $x$ & \\
\hline 31 & Rżąka & $x$ & & \\
\hline
\end{tabular}

Most frequently, these situations occur simultaneously in housing estates. In addition to the already mentioned densifications within the perimeter of the housing estates, which occur nearly in all the analyzed housing estates, in 13 of them, a partial shift of their edge can be additionally observed, and seven share the neighborhood with new complexes of residential buildings. In four housing estates, all these phenomena were observed.

Considering the types and intensity of densifications, the housing estates that demonstrate the most far-reaching spatial changes are the Dywizjonu 303 housing estate (34.2\%), the Oświecenia housing estate (30.6\%), and Kurdwanów (30.0\%) (Figure 7).

In the Dywizjonu 303 and Kurdwanów housing estates, intensive densifications with single buildings and clusters thereof take place within the perimeter of the housing estates, as well as in their outskirts, in some cases shifting the original edge of the housing estate, which has changed the original valuable urban composition. Furthermore, they are accompanied with areas of intensive residential development. In the housing estates in 
Czyżyny (the Dywizjonu 303 housing estate and the II Pułku Lotniczego housing estate), unoccupied areas on the southern side of the runway have been adapted for the Nowe Czyżyny housing estate. Due to certain controversies and a significant influence of this project on the housing estates in Czyżyny, this case is described in more detail in Section 3.3.

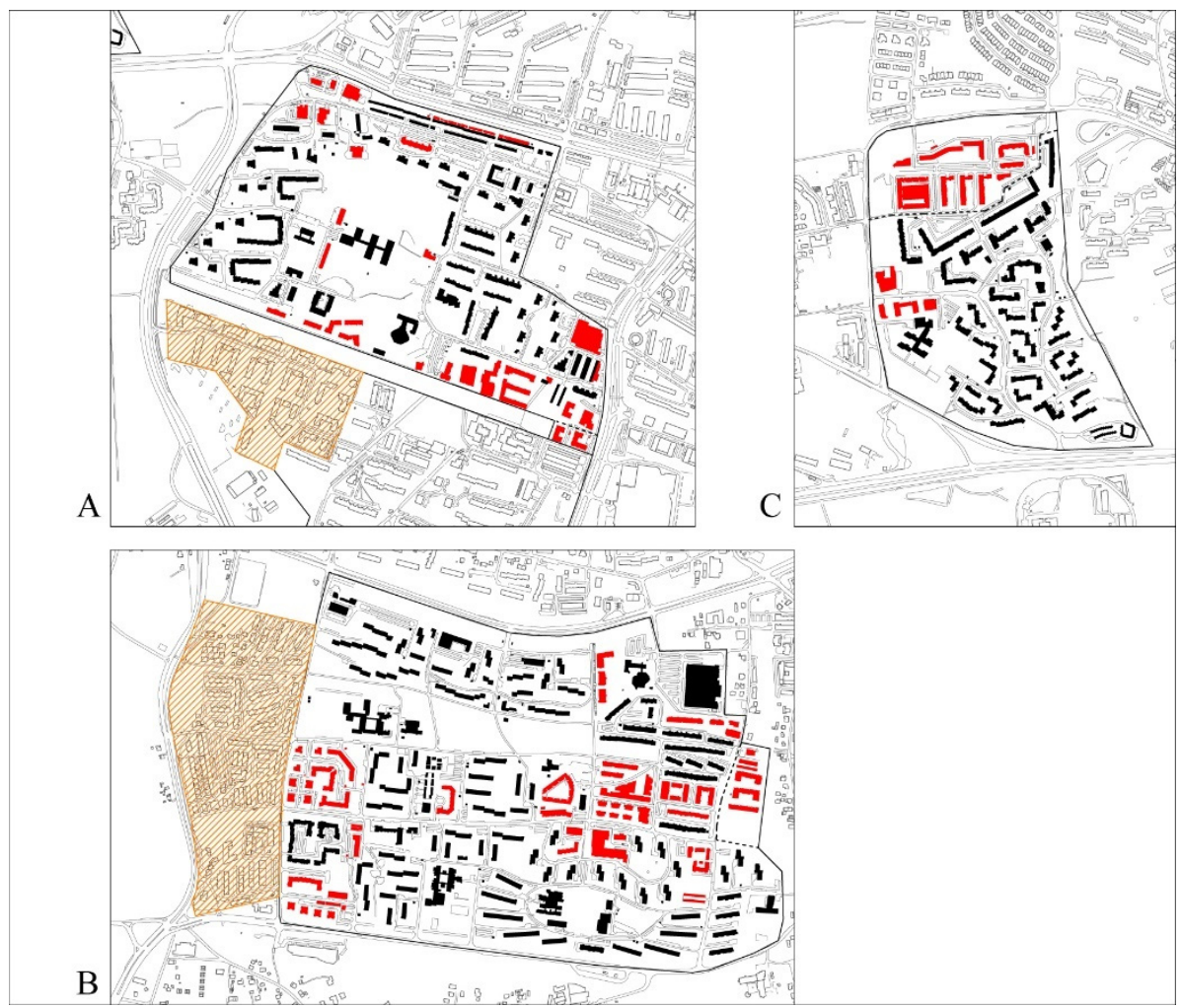

Figure 7. Cracow large-panel housing estates with the highest intensity of densification: (A) - the Dywizjonu 303 housing estate; (B)—the Kurdwanów housing estate; (C)—the Oświecenia housing estate. Color legend: black-developments from before 1995; red-densification-developments from after 1995; orange-other multi-family housing areas next to the large-panel housing estates.

In the Oświecenia housing estate, there are no single buildings added inside the housing estate; however, there are two distinct clusters of new buildings in the edge area. In the context of the formula of defining new buildings as belonging or not belonging to a housing estate as adopted in this paper, regarding the complex of buildings in the northern part of the housing estate as an extension of the Oświecenia housing estate instead of an independent project may seem debatable. This is due to the fact that this part of the development is generally regarded as officially belonging to this housing estate as its extension. It is worth pointing out that the southern part of the housing estate, with a characteristic meandering structure, has maintained its urban layout and there are no new additions between apartments blocks there.

The housing estates that have no or the lowest degree of densifications, i.e., Ceglana, Kombatantów, Ugorek, Tysiąclecia, and Piaski Nowe, demonstrate their original, nearly unchanged layout of the entire development. However, in the latter, a cluster of multifamily residential buildings has emerged adjacent to it, and it is still being extended.

\subsection{Selected Examples of Spatial Devastation}

The above considerations, presented in Sections 3.1 and 3.2, allow selecting examples in which adding new structures to large-panel housing estates recognized as urban heritage structures entails squandering of their potential by destroying their urban composition and other urban values. 
The influence of this type of densifications can be considered according to the set of the following qualitative criteria, characterizing the basic aspects of the functioning of housing estates:

- Influence on the original urban layout of the housing estate and its legibility;

- Influence on the continuity of open public spaces and green areas and on the quality thereof;

- Influence on the amount of public open areas;

- Influence on the existing historical and cultural assets;

- Influence on the mixed-use development.

Ones of blatant examples in this respect are the aforementioned housing estates in Czyżyny: Dywizjonu 303 and II Pułku Lotniczego, which are located on both sides of the historic runway of the former airport Rakowice-Czyżyny (Figures 8 and 9). Aggressive measures undertaken by developers (level of densification: $34.2 \%$ and $19.2 \%$ ) caused utter devastation of the post-military heritage of the area, which besides constituting a true loss in the scale of the city directly affects the adjacent large-panel housing estates. The new development is partially fenced off and almost monofunctional. This is an example of the densification process, which is aimed at private interest, not the common one, especially in the context of the neighboring large-panel housing estates [35].

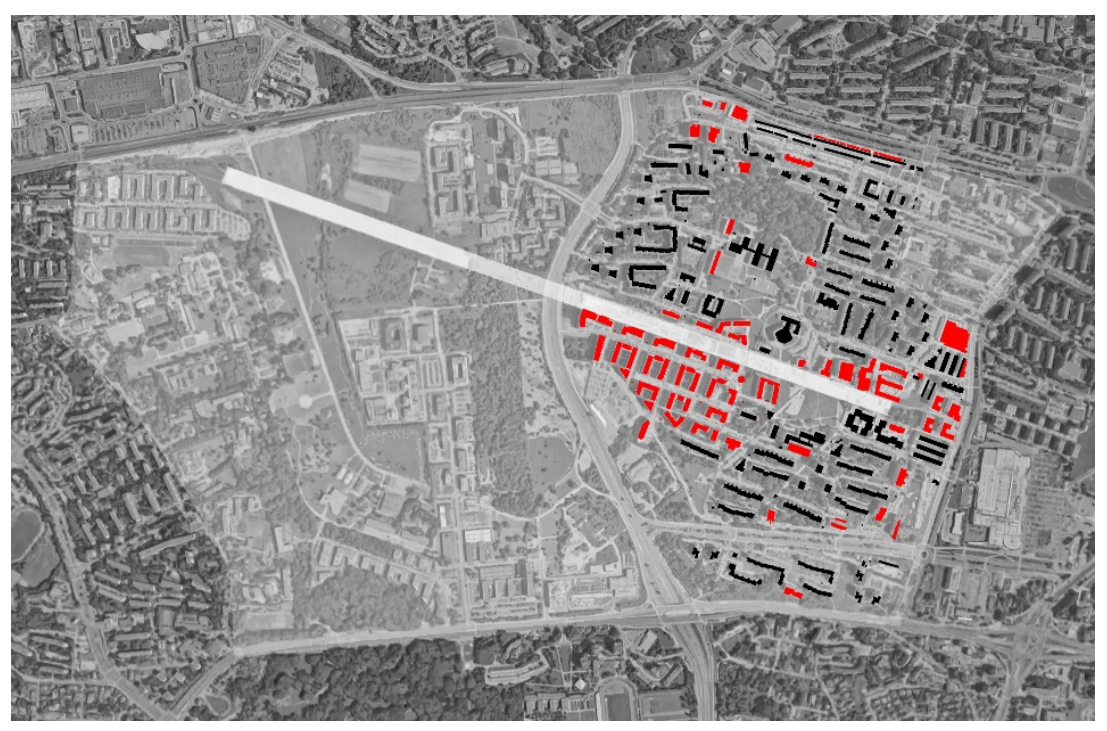

Figure 8. Densifications of housing estates in Czyżyny in the context of destruction of their main potential-the former runway. Based on an ortophotomap (www.maps.google.com; accessed on 5 December 2021). Color legend: white area-approximate area of the former airport RakowiceCzyżyny with a specified runaway (white stripe); black buildings—developments from before 1995 (mostly within the scheme of the construction of the housing estates in Czyżyny); red—densificationdevelopments from after 1995.

Similarly enough, metamorphoses observed in the Bohaterów Września housing estate and the Piastów housing estate in Mistrzejowice move toward a particularly unfavorable end. Devastating densifications (28.2\% and $10.9 \%)$ take place predominantly on their northern and western outskirts, shifting and changing the character of their edges (Figures 10 and 11), which according to the original design were planned as a green buffer zone [42].

From the side of the Bohaterów Września housing estate, the green buffer zone is provided by Planty Mistrzejowickie park, and from the north, it is provided by areas of the former defense ring of the Cracow Fortress, with still preserved structures of the former forts: Mistrzejowice and Batowice, surrounded by abundant vegetation, once fulfilling camouflage purposes. The document 'Program of the Cracow Fortress Protection Plan' [52] describes this area as worth protecting. 
The problems connected with the densification process described in the examples above are associated with-inter alia-their negative influence on the urban layout of these housing estates, breaking of the continuity of their public spaces, devastation of the historical and cultural potential, strengthening of monofunctionality, and appropriation of valuable green areas. Taking over green areas by aggressive investments constitutes a serious problem. Key green areas disappear and their continuity is broken, which causes irreversible destruction of these areas. It is a significant loss not only in the context of the housing estates themselves but the entire city, too. Urban values of the housing estates have been irreversibly destroyed.

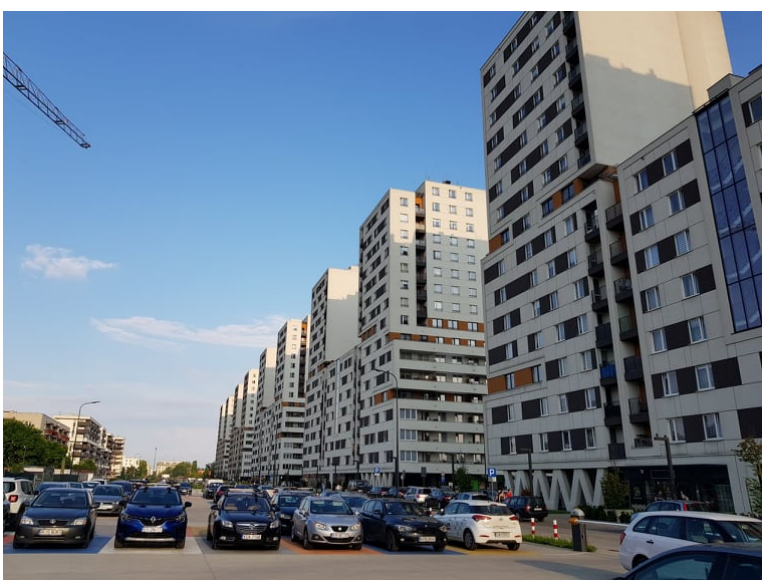

(a)

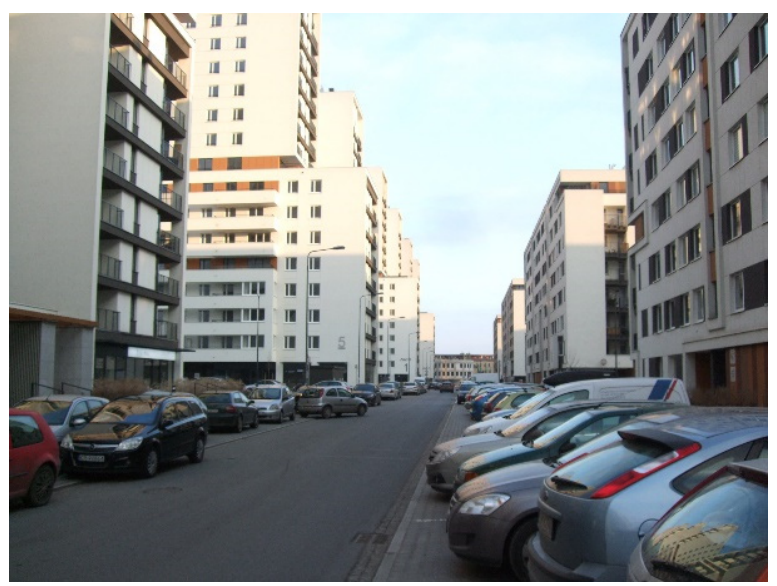

(b)

Figure 9. Character of an open space in the multi-family residential development in Czyżyny: (a) Arrangement of the area of the former runway of the Rakowice-Czyżyny airfield along with the residential development; (b) Character of a space in between the buildings. Photos: by author.

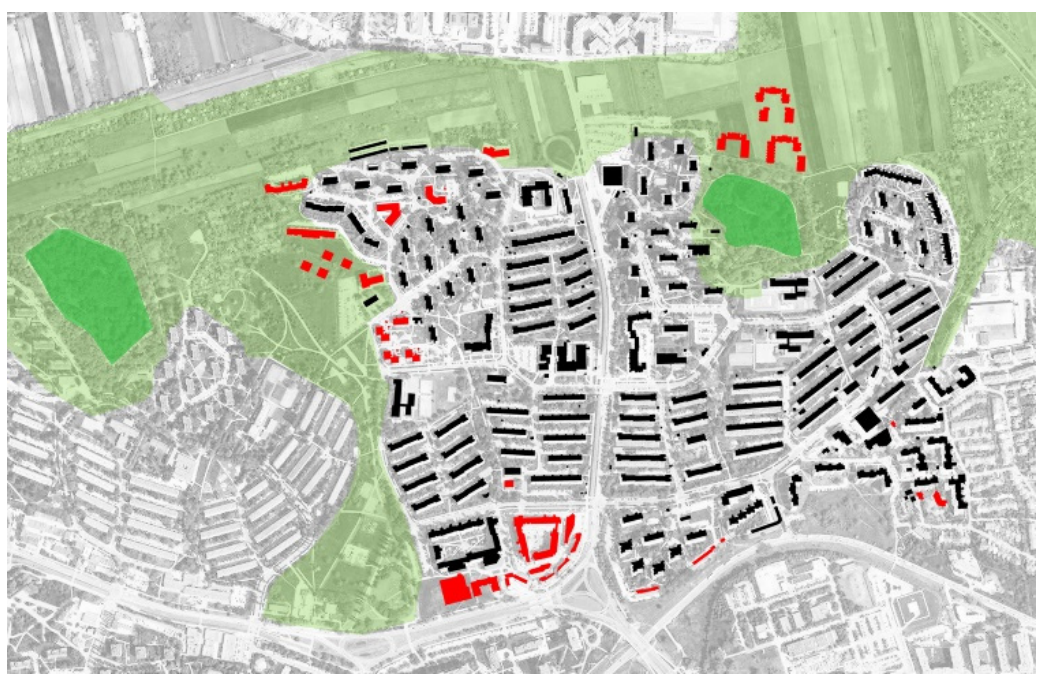

Figure 10. Densifications of housing estates in Mistrzejowice in the context of green areas of the fortress constituting their buffer zone and other green areas enveloping the housing estates (green). Color legend: black buildings-developments from before 1995 (mostly within the scheme of the construction of the Bohaterów Września i Piastów housing estates); red-densification-developments from after 1995. Based on an ortophotomap (www.maps.google.com, accessed on 5 December 2021). 


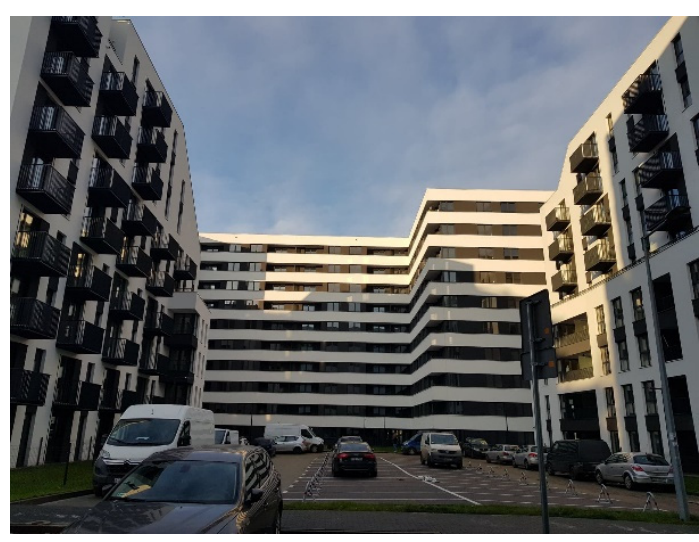

(a)

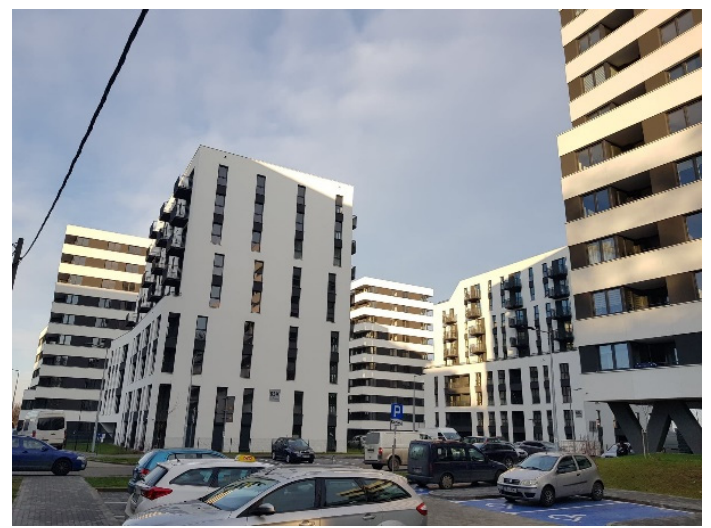

(b)

Figure 11. (a,b) Intensive multi-family residential development on the northern side of the Piastów housing estate. Photos: by author.

\section{Discussion}

One of the important reasons for undertaking the work was to draw attention to the growing problem of densification of large-panel housing estates with new buildings and at the same time destruction of Late Modernist urban structures, which are often recognized as heritage. Frequently, it is quite excessive and chaotic, and it constitutes a threat to their functioning as a valuable housing environment. Single buildings or clusters thereof built within the perimeter of housing estates as well as in their outskirts lead to the shifting of their edges' (Table 3) appropriate valuable open space, destroying their composition. Over time, such changes can lead to complete obliteration of the original design idea in the entire housing estate or a fragment thereof. In this way, the main potential of such housing estates, which results predominantly from their urban advantages, such as urban composition and its functional and spatial logic, large amounts of open public space, and abundance of greenery, is gradually annihilated.

The results presented herein demonstrated the possibility of obtaining essential information on this problem by quantitative determination of the degree of densification of large-panel housing estates. Upon the example of a comprehensive analysis of all (31) large-panel housing estates in Cracow, carried out on the basis of measurements and calculations of the additional built-up area performed on the basis of available materials (vector maps, satellite images, and planning materials), an average size of densification with new buildings was determined. For all the housing estates, this average is already $15.4 \%$, whereas in some of them, it is very high-it has reached the value of nearly $35 \%$ (Table 1, Figure 3).

In light of the above, it is clear that the qualitative analysis may be more effective in the presence of quantitative data. Problems of threats and damages to the existing, already historic urban composition, caused by uncoordinated, chaotic additions to large-panel housing estates, incompatible with their initial plans, are illustrated upon selected examplesthe housing estates in Czyżyny (Dywizjonu 303 and II Pułku Lotniczego; Figure 8) and selected housing estates in Mistrzejowice (Bohaterów Września and Piastów; Figure 10). The high density and chaotic arrangement of a new development caused significant spatial changes, which has a negative influence on the urban layout of these housing estates. They have lost valuable green areas, and the continuity of public spaces has been broken. Moreover, the densifications have led to devastation of the historical and cultural potential. As a result, the housing estates have lost some of their advantages irreversibly.

It proves that it is important to link quantitative data and qualitative criteria (e.g., influence of the densification on the urban layout, continuity of public spaces, resources of greenery, existing historical and cultural assets, mixed-use development) to obtain a proper characterization of the functioning of the estates. 
According to the observations, a considerable share of the new buildings covers multi-family residential developments, which intensifies the monofunctionality of the housing estates. A similar effect can be caused by enclaves of such developments in the direct proximity of large-panel housing estates; hence, they have been taken into account in this study. Housing estates and their immediate surroundings need to be integrated within the urban context $[53,54]$. However, the study does not consider any detailed data relating to them, limiting solely to indicating their location. Likewise, the study does not focus on the quantitative determination of the function that emerges as new buildings appear. A quantitative functional and spatial analysis could be the next step, addressing transformations in housing estates in more detail. It has been found that despite the fact that prefabricated housing estates are a legacy of the Modernist segregation of functions and as such they are burdened with a number of issues, such as monofunctionality, monotony of development, repetitiveness of forms, and low quality of architecture of apartments blocks, they are often characterized by a functional and spatial logic and abundance of green areas. Frequently, the overall urban layout of a housing estate corresponds to local conditions, making use of natural advantages (the lay of the land, vicinity of valuable landscapes). The risks of losing these advantages caused by chaotic development may be mitigated to a certain extent by local spatial development plans. In the case of the housing estates in Cracow, such plans cover only 14 out of the 31 housing estates or complexes thereof investigated in this study (Table 2).

In this context, what deserves attention is an opinion that in the Study of Spatial Development Conditions and Directions in force [44], which provides the foundations for all the local spatial development plans and administrative decisions in this area, and consequently the grounds for building permits to be issued, the protection of valuable housing projects from that period is insufficient and ineffective [25]. In the scientific debate, there are more and more voices about the need to protect valuable urban structures of the second half of the 20th century [55-57]. Therefore, an interesting concept is the introduction of the term 'urban heritage structures' as a protection tool at the level of the local law (planning documents, study, local spatial development plans). These structures would comprise-among others-valuable 20th-century and contemporary projects of different scales and uses [2].

In the context of the results of studies and analyses presented in this paper, it should be concluded that some housing estates have lost some of their advantages irreversibly. Many housing estates still have such values, and it is important not to lose this potential.

However, it should be noted that following an idea of the 'compact city', many European planning strategies consider urban densification as one of the tools to promote sustainable urban development. One may agree with that opinion only when the densification results from a wider, comprehensive development plan and not from individual, uncoordinated decisions: not those aimed at private interest, but at the common one. It needs to be a thoroughly planned densification process [58], which is usually complex and slow [59]. Moreover, regeneration policies for the housing estates should be considered in view of a wider urban context of the city, which can be labeled as an outward-looking approach [60,61].

Furthermore, investing in such housing estates is a positive thing in itself, especially if new service facilities are introduced, which makes the functional program of the estate more diverse. Mixed use promotes sustainable urban development as well [62,63].

Therefore, even though quite paradoxically, it could be stated that up to a point, the current densifications protect housing estates from their functional degradation, at the same time, they lead to their spatial degradation and destroy their advantages. However, it is worth noticing that there is still a chance to improve the situation of housing estates by undertaking rational and consistent measures in the field of architecture and urban planning, which can change not only the living standards offered to residents but also the very image of housing estates. 
The methodology proposed and verified within the scheme of the research presented in this publication can be used as a tool for analyzing the problem of densification of large-panel housing estates in other towns and cities.

\section{Conclusions}

The goal of the research presented in this paper is to demonstrate the scales and character of densifications of the large-panel housing estates built in the second half of the 20th century, which pose a threat of devastation of their urban layouts, which are often recognized as heritage.

The paper applies a quantitative and qualitative approach to present spatial transformations that take place within such housing estates. The study area comprised housing estates in Cracow, the main city of the Province of Małopolskie, which after filtering out certain local specificity demonstrates many tendencies and mechanisms characteristic for other big cities of Poland.

The paper illustrates the scale of the problem, subsequently classifying the ways in which these housing estates have been transformed in terms of their densifications. Two main tendencies have been observed: adding buildings or clusters of buildings within the perimeter of housing estates and in their outskirts, leading to shifting of their edges. It also points to the essence of functional and spatial changes in the direct vicinity of large-panel housing estates, consisting of building a new complex of multi-family residential buildings, demonstrating the potential negative influence on their functioning. On the basis of the analysis results, the paper demonstrates the threat of devastation of urban layouts of such housing estates and their main potential—green areas.

This paper constitutes a voice in a discussion devoted to the condition, but most of all to the future of large-panel housing estates, particularly in terms of their protection and stopping some unfavorable tendencies of urban destruction. It fills the gap in the existing studies focusing on this problem, particularly in the context of the ongoing debate on the significance of urban planning achievements in the second half of the 20th century and recognizing valuable urban layouts as heritage.

All measures leading to the development and improvement of the quality of largepanel housing estates are desirable. Nevertheless, they should constitute an element of a well-coordinated and comprehensive process, instead of a sum of one-off interventions, paying no or little heed to the existing context, particularly the ones that disregard public interest in favor of the private one. The study results presented herein indicate that chaotic densifications in such housing estates may reach a surprisingly big scale. Therefore, the presented method of analyzing the effects of this process in a systematic approach seems to be useful for controlling and rationalizing its propagation, in particular for revealing and eliminating the negative tendencies that emerge. The knowledge obtained this way may prove valuable in prognostic studies devoted to urban development, in the optimization of relevant formal and legal solutions, as well as in optimizing current management activities.

The research presented in this paper was limited to the problem of the percentage of the increase in the built-up area of these housing estates and the character of their densification as well as to demonstrating a threat of devastation of their urban layouts. Therefore, further research can develop the problem of densification and its effects on such housing estates in a more complex way. For instance, it is possible to study the impact of the densification process on the percentage of services and the mix of services, the degree of fragmentation of green areas, etc. The research topic can cover multidisciplinary issues, for example densification studies can be integrated with sociological aspects, such as residents' population, population by age, by income, and by nationality. It is recommended to conduct further research from the aspect of creating formal barriers to prevent the uncontrolled densification of large-panel housing estates.

The sustainable development of cities based on the concept of a compact city requires an appropriate density and intensity of development, which means that measures directed toward increasing this intensity within city limits are rational in many cases. Nevertheless, 
they need to be optimized, and they must not be implemented at the expense of existing heritage structures and their residents. This paper may constitute a source of information on tendencies of transformations occurring in large-panel housing estates as well as a source of inspiration to take actions aimed at the rationalization of these processes.

Funding: This research received no external funding.

Institutional Review Board Statement: Not applicable.

Informed Consent Statement: Not applicable.

Data Availability Statement: Data available in a publicly accessible repositories—they are all showed in the 'References' section.

Conflicts of Interest: The author declares no conflict of interest.

\section{References}

1. Corbusier, L. Karta ateńska (orig. La Charte d'Athènes); Fundacja Centrum Architektury: Warszawa, Poland, 2017; Document Adopted at the IV Congrès Internationaux d'Architecture Moderne (CIAM) held in 1933.

2. Gyurkovich, M.; Szarata, A.; Zuziak, Z.K.; Ogrodnik, D.; Faron, A.; Ziobro, A.; Poklewski-Koziełł, D.; Suchoń, F.; Tota, P.; Sotoca, A.; et al. Model Przestrzennej Struktury Krakowa. Perspektywa Planistyczna. Etap II Zdefiniowanie Modelu Przestrzennej Struktury Krakowa; Reaserch project for BPP UM Kraków, Instytut Projektowania Urbanistycznego, Wydział Architektury; Politechnika Krakowska: Kraków, Poland, 2017.

3. Białkiewicz, A.; Żychowska, M.J.; Stelmach, B. Assets of Modern Culture: An Outline of Conservation Issues. Wiadomości Konserw. 2020, 63, 152-162. [CrossRef]

4. Sendi, R.; Kerbler, B. The Evolution of Multifamily Housing: Post-Second World War Large Housing Estates versus Post-Socialist Multifamily Housing Types in Slovenia. Sustainability 2021, 13, 10363. [CrossRef]

5. García-Pérez, S.; Oliveira, V.; Monclús, J.; Díez Medina, C. UR-Hesp: A methodological approach for a diagnosis on the quality of open spaces in mass housing estates. Cities 2020, 103, 102657. [CrossRef]

6. Dekker, K.; Van Kempen, R. Large housing estates in Europe: Current situation and developments. Tijdschr. Econ. Soc. Geogr. 2004, 95, 570-577. [CrossRef]

7. Díez Medina, C.; Monclús, J. Dealing with Mass housing estates legacy: The need of specific diagnoses from an urban design perspectives. In Proceedings of the 24th ISUF 2017-City and Territory in the Globalization Age, Valencia, Spain, 27-29 September 2017; Universitat Politčcnica Valčncia: Valencia, Spain, 2017; pp. 309-322. [CrossRef]

8. Szczerek, E. Rewitalizacja Osiedli Wielkoptytowych a Ciagłość i Komplementarność Przestrzeni Publicznej Miasta; Wydawnictwo Politechniki Krakowskiej: Kraków, Poland, 2018.

9. Van Beckhoven, E.; Van Kempen, R. Towards more social cohesion in large post-second world war housing estates? A case study in Utrecht, the Netherlands. Hous. Stud. 2006, 21, 477-500. [CrossRef]

10. Smagacz-Poziemska, M.; Bukowski, A.; Jabłońska, B. Wykluczone Sasiedztwa. Społeczne Aspekty Rewitalizacji w Przestrzeni w Wielkiego Miasta; Instytut Socjologii Uniwersytetu Jagiellońskiego: Kraków, Poland, 2007.

11. Gorczyca, K. The Social Transformation of Large Housing Estates in Poland at the Turn of the 21st Century. Czech Sociol. Rev. 2016, 52, 861-892. [CrossRef]

12. Wassenberg, F. Large social housing estates: From stigma to demolition? Neth. J. Hous. Environ. Res. 2004, 19, 223-232. [CrossRef]

13. Brattbakk, I. Post-war large housing estates in Norway? Well-kept residential areas still stigmatised? Neth. J. Hous. Environ. Res. 2004, 19, 311-332. [CrossRef]

14. Racoń-Leja, K.; Kwiatkowski, K. W poszukiwaniu bezpiecznego osiedla-Eksperyment na krakowskim Nowym Bieżanowie. Autoportret 2005, 4, 28-29.

15. Jeżak, J.; Rydzik, W.; Węglowski, M. Strategie Rehabilitacji Blokowisk; Rębowska, A., Ed.; IRM: Kraków, Poland, 2006.

16. Högberg, L.; Lind, H.; Grange, K. Incentives for improving energy efficiency when renovating large-scale housing estates: A case study of the swedish million homes programme. Sustainability 2009, 1, 1349-1365. [CrossRef]

17. Jarczewski, W. Procedura badawcza i wyniki prac prowadzonych w ramach diagnozy. In Rewitalizacja Miast Polskich-Diagnoza; Ziobrowski, Z., Jarczewski, W., Eds.; IRM: Kraków, Poland, 2010; Volume 8, pp. 13-21.

18. Jarczewski, W. Skala degradacji miast w Polsce. In Rewitalizacja Miast Polskich—Diagnoza; Ziobrowski, Z., Jarczewski, W., Eds.; IRM: Kraków, Poland, 2010; Volume 8, pp. 57-64.

19. Raport—Stan Mieszkalnictwa w Polsce; Ministerstwo Rozwoju; Marzec 2020 (Report—The State of Housing in Poland; Ministry of Development; March 2020). Available online: https:/ /www.gov.pl/web/rozwoj-technologia/raport-o-stanie-mieszkalnictwa (accessed on 2 November 2021).

20. Szafrańska, E. Transformations of large housing estates in post-socialist city: The case of Łódź, Poland. Geogr. Pol. 2014, 87, 77-93. [CrossRef]

21. Protić, I.B.; Mitković, P.; Vasilevska, L. Toward Regeneration of Public Open Spaces within Large Housing Estates-A Case Study of Niš, Serbia. Sustainability 2020, 12, 10256. [CrossRef] 
22. Battisti, L.; Pille, L.; Wachtel, T.; Larcher, F.; Säumel, I. Residential Greenery: State of the Art and Health-Related Ecosystem Services and Disservices in the City of Berlin. Sustainability 2019, 11, 1815. [CrossRef]

23. Schwarz, N.; Haase, A.; Haase, D.; Kabisch, N.; Kabisch, S.; Liebelt, V.; Rink, D.; Strohbach, M.; Welz, J.; Wolff, M. How are urban green spaces and residential development related? A synopsis of multi-perspective analyses for Leipzig, Germany. Land 2021, 10, 630. [CrossRef]

24. Kopecká, M.; Szatmári, D.; Rosina, K. Analysis of urban green spaces based on sentinel-2A: Case studies from Slovakia. Land 2017, 6, 25. [CrossRef]

25. Gyurkovich, M.; Sotoca, A.; Szarata, A.; Szczerek, E.; Matusik, A.; Poklewski-Koziełł, D.; Suchon, F. housing estates from the second half of the twentieth century as urban heritage structures: Example of housing estates in Mistrzejowice, Cracow. Wiadomości Konserw. 2021, 65, 54-65.

26. Temelová, J.; Slezáková, A. The changing environment and neighbourhood satisfaction in socialist high-rise panel housing estates: The time-comparative perceptions of elderly residents in Prague. Cities 2014, 37, 82-91. [CrossRef]

27. Kabisch, S.; Grossmann, K. Challenges for large housing estates in light of population decline and ageing: Results of a long-term survey in East Germany. Habitat Int. 2013, 39, 232-239. [CrossRef]

28. Kovács, Z.; Hegedûs, G. Gated communities as new forms of segregation in post-socialist Budapest. Cities 2014, 36, 200-209. [CrossRef]

29. Włodarczyk, M. (Ed.) Krakowskie Osiedla Modernizmu lat 1945-1990. Wybrane Przykłady; SARP Oddział Kraków: Kraków, Poland, 2014.

30. Tokajuk, A. Gry mieszkaniowe'-Wybrane problemy kształtowania zabudowy mieszkaniowej w Polsce XXI wieku. Analiza krytyczna. Archit. Artibus 2015, 4, 65-71.

31. Schneider-Skalska, G.; Lorek, A. The housing environment of Cracow-Selected areas, selected problems. In Cracow: Selected Problems of the Urban Structure Evolution; Gyurkovich, J., Matusik, A., Suchoń, F., Eds.; Wydawnictwo Politechniki Krakowskiej: Kraków, Poland, 2016; pp. 53-82.

32. Pancewicz, Ł. O potrzebie nowego modernizmu. Autoportret 2021, 1, 80-85.

33. Celińska-Janowicz, D. Druga młodość czy upadek? Warszawskie osiedle Służew nad Dolinką w okresie transformacji. Studia Reg. Lokalne 2010, 1, 89-104.

34. Masztalski, R.; Michalski, M. Podatność osiedli wielkopłytowych z drugiej połowy XX wieku we Wrocławiu na procesy rewitalizacyjne. Bud. Arch. 2018, 17, 101-108. [CrossRef]

35. Szczerek, E. Loss of Potential: Large-Panel Housing Estates-Czyzyny Case. IOP Conf. Series Mater. Sci. Eng. 2019, $471,092034$. [CrossRef]

36. Crisan, R.; Macri, Z.; Panait, A. (Eds.) Visions on Mass-Housing Sustainable Rehabilitation; Editura Universitară Ion Mincu: Bucuresti, Romania, 2011.

37. Gyurkovich, M. (Ed.) Future of the City: Mass HOUSING Estates or Multifamily Housing Complexes? Eco Rehab 3 Cracow 2012 Cracow University of Technology: Krakow, Poland, 2012.

38. Kristiánová, K. Post-socialist transformations of green open spaces in large scale socialist housing estates in Slovakia. Procedia Eng. 2016, 161, 1863-1867. [CrossRef]

39. Treija, S.; Bratuškins, U.; Korolova, A. Urban densification of large housing estates in the context of privatisation of public open space: The case of Imanta, Riga. Arch. Urban Plan. 2018, 14, 105-110. [CrossRef]

40. Chmielewski, J.M.; Mirecka, M. Modernizacja Osiedli Mieszkaniowych; Oficyna Wydawnicza PW: Warszawa, Poland, 2007.

41. Jeżak, J.; Nejman, M.; Wierzchowski, M. Wielokryterialna Analiza 19 Osiedli Zabudowy Blokowej Położonych na Terenie Gminy Miejskiej Kraków; IRM: Kraków, Poland, 2011.

42. Karpińska, M.; Leśniak-Rychlak, D.; Wiśniewski, M. (Eds.) Witold Cęckiewicz; Instytut Architektury: Kraków, Poland, 2015; Volume I-II.

43. Fabiański, M.; Purchla, J. Przewodnik po Architekturze Krakowa; Wydawnictwo Literackie: Kraków, Poland, 2001.

44. Studium Uwarunkowań i Kierunków Zagospodarowania Przestrzennego Miasta Krakowa (2003), Uchwała RMK Nr XII/87/03 z dnia 16 kwietnia 2003 r. Zmiana Studium Uwarunkowa'n i Kierunków Zagospodarowania Przestrzennego Miasta Krakowa, t. I-III, załącznik do Uchwały nr CXII/1700/14 Rady Miasta Krakowa z 9 lipca 2014r., Biuro Planowania Przestrzennego UM Krakowa, Kraków 2014 (2003 Spatial Development Study, Resolution of the Cracow City Council of 16 April 2003 No. XII/87/03 together with the update vol. I-III dated on 9 July 2014). Available online: https:/ / www.bip.krakow.pl/?bip_id=1\&mmi=48 (accessed on 2 November 2021).

45. Seibert, K. Plan Wielkiego Krakowa; Wydawnictwo Literackie Kraków: Kraków, Poland, 1983.

46. Rehabilitacja Zabudowy Blokowej Osiedli w Krakowie. Available online: https://www.bip.krakow.pl/?dok_id=51896 (accessed on 2 November 2021).

47. Ilmurzyńska, K. Ewolucja przestrzenna Ursynowa Północnego. PUA 2018, 1, 203-218. [CrossRef]

48. Niezabitowska, E.D. Metody i Techniki Badawcze w Architekturze; Wydawnictwo Politechniki Śląskiej: Gliwice, Poland, 2014.

49. Lynch, K. Good City Form; The MIT Press: Cambridge, MA, USA, 1984.

50. MSIP Kraków: Miejski System Informacji Przestrzennej. Available online: https://msip.krakow.pl/ (accessed on 2 November 2021).

51. Biuletyn Informacji Publicznej. Miasto Kraków. Available online: https:/ /www.bip.krakow.pl/ (accessed on 2 November 2021). 
52. Myczkowski, Z.; Wielgus, K.; Chajdys, K.; Maj, A.; Mikulski, J.; Leonowicz, P.; Rymsza-Mazur, W.; Staniewska, A.; ŚrodulskaWielgus, J.; Latusek, K. Program Planu Ochrony Twierdzy Kraków (Studium Parków Kulturowych i Stref Ochrony Krajobrazu Warownego); Reaserch project for WKiDN UM Kraków, Instytut Architektury Krajobrazu, Wydział Architektury; Politechnika Krakowska: Kraków, Poland, 2014.

53. Sotoca, A. (Ed.) After the Project-Updating Mass Housing Estates; II EcoRehab, Barcelona 2011; UPC: Barcelona, Spain, 2012.

54. Balla, R. A Sustainable Urban Concept for Housing Estates: Plot, Patch, Part. Period. Polytech. Arch. 2018, 49, 135-143. [CrossRef]

55. Wẹcławowicz-Gyurkovich, E. Podsumowanie ogólnopolskiej konferencji ‘Ochrona dziedzictwa architektury polskiej II połowy XX wieku, Warszawa 16-17.XI.2016'. Wiadomości Konserw. 2017, 49, 7-14.

56. Gaczoł, A. Kryteria dotyczące wpisu obiektów architektonicznych z II połowy XX wieku do rejestru zabytków. Teoria i praktyka. Wiadomości Konserw. 2017, 49, 163-180.

57. Kadłuczka, A. Posłowie do Ogólnopolskiej Konferencji ‘Ochrona dziedzictwa architektury i urbanistyki II połowy XX wieku'. Wiadomości Konserw. 2017, 49, 15-18.

58. Skovbro, A. Urban densification-A sustainable urban policy? In The Sustainable City II; Brebbia, C.A., Martin-Duque, J.F., Wadhwa, L.C., Eds.; WIT Press: Southampton, UK, 2002; pp. 517-527.

59. Puustinen, S. Urban densification as a challenge for city planning. Improving conditions and processes of infill developments. In Proceedings of the Conference: Plannord Conference in Kungliga Tekniska Högskolan, Stockholm, Sweden, 20-22 August 2015.

60. Hall, P. Regeneration Policies for Peripheral Housing Estates: Inward- and Outward-looking Approaches. Urban Stud. 1997, 34, 873-890. [CrossRef]

61. Muliuolyte, J. Rediscovering large scale housing estates in post socialist cities. J. Arch. Urban. 2013, 37, 51-58. [CrossRef]

62. Yang, H.; Fu, M.; Wang, L.; Tang, F. Mixed Land Use Evaluation and Its Impact on Housing Prices in Beijing Based on Multi-Source Big Data. Land 2021, 10, 1103. [CrossRef]

63. Maleki, M.; Zain, M.; Ismail, A. Variables communalities and dependence to factors of street system, density, and mixed land use in sustainable site design. Sustain. Cities Soc. 2012, 3, 46-53. [CrossRef] 